\title{
THE IMPACT OF VARIOUS CATIONS ON THE SORPTION OF MANGANESE IN THE THALLUS OF FRESHWATER ALGAE Spirogyra sp. AND SEA ALGAE Palmaria palmata
}

\author{
WPŁYW RÓŻNYCH KATIONÓW NA SORPCJĘ MANGANU \\ W PLESZE SŁODKOWODNYCH GLONÓW Spirogyra sp. \\ ORAZ W GLONACH MORSKICH Palmaria palmata
}

\begin{abstract}
Due to their occurrence in very different conditions and high resistance to physical and chemical factors, algae are pioneers colonising new environments and their sorption properties are used in biomonitoring and water remediation. The efficiency of the process of heavy metal sorption in algae used for in situ tests depends on abiotic factors, such as the chemical composition of water. Freshwater algae Spirogyra sp. were used in tests. Algae were exposed in the laboratory in manganese chloride solutions with various contents of other cations, including heavy metals and macronutrients. It has been shown that some heavy metals may desorb manganese bound to the surface of algae as a result of ion exchange in the following sequence: $\mathrm{Cd}^{2+}<\mathrm{Mn}^{2+} \approx \mathrm{Zn}^{2+}<\mathrm{Cu}^{2+}$. It has been also found that the competitiveness of sorption of cations naturally present in the alga environment versus $\mathrm{Mn}^{2+}$ cations changes in the sequence $\mathrm{Na}^{+}<\mathrm{Ca}^{2+}<\mathrm{H}^{+}$, defined for the concentrations referring to the cation unit charge. The results of tests were compared to the results of dried sea algae Palmaria palmata analyses.
\end{abstract}

Keywords: Spirogyra sp., Palmaria palmata, ion exchange, heavy metals, competitiveness of sorption

\section{Introduction}

The efficiency of the process of heavy metal sorption in algae used for in situ tests depends on abiotic factors, such as temperature, $\mathrm{pH}$, photosynthetically active light intensity and the presence of other cations or humic substances which are responsible, inter alia, for the formation of hardly soluble metal compounds or their complexes. Due to the complexity of physical and chemical properties of the aquatic environment and interactions between various elements of the ecosystem, it is difficult in natural conditions to determine their impact on the kinetics and sorption equilibria. Currently, numerous laboratory tests are

\footnotetext{
${ }^{1}$ Chair of Biotechnology and Molecular Biology, Opole University, ul. kard. B. Kominka 6, 45-032 Opole, Poland, phone +48 7740160 42, fax +48 774016050

${ }^{2}$ Department of Environment Protection and Modelling, Jan Kochanowski University, ul. Świętokrzyska 15 , 25-406 Kielce, Poland, phone +48 4134964 34, fax +48 4134964 18,

*Corresponding author: mrajfur@o2.pl
} 
conducted on heavy metal sorption parameters in living and prepared algae [1]. The objective of these tests is to evaluate the possibility of using algae in biomonitoring and surface water remediation processes $[2,3]$.

For example, differences were observe in the sorption properties of different genera and species of algae, caused, inter alia, by the physiological and morphological structure of the thallus, the biomass sampling site and the method of algae preparation for the analysis [4]. The authors agree that the main mechanism of heavy metal sorption in biomass is ion exchange. The algae cell wall is made, inter alia, of polysaccharides, lipids, proteins and alginic acids. In some genera of algae, additional components of the cell wall include calcium carbonate, chitin (polymer of $\mathrm{N}$-acetylglucosamine), silica and alginates (alginic acid salts). The cell wall has 3-5 nm pores that make it permeable to low-molecular weight substances, such as water, metal cations and gaseous substances. The functional groups responsible for the addition of heavy metal cations include amino, acetyl, hydroxyl, sulfo, carbonyl and carboxyl groups [5].

To assess the sorption parameters, the process kinetics is usually described and the parameters of equilibrium and sorption capacity of algae are measured, eg [6]. The results of the previously completed research showed that the dynamic equilibrium during heavy metal sorption in Palmaria palmata is achieved after approximately 50 minutes. During that time, approximately $87 \%$ of $\mathrm{Mn}^{2+}$ cations, $95 \%$ of $\mathrm{Cu}^{2+}$ cations, $96 \%$ of $\mathrm{Zn}^{2+}$ cations and $97 \%$ of $\mathrm{Cd}^{2+}$ cations, with reference to their total sorption capacity, accumulate in algae. In the first 10 minutes of the process, approximately $60-70 \%$ of heavy metal cations are absorbed [7].

In order to describe the equilibrium, different mathematical models are applied, including Freundlich isotherm model [8], Redlich-Peterson isotherm model [9] and, most frequently, Langmuir isotherm model $[10,11]$ on the basis of which it is possible to determine the sorption capacity. However, it should be noted that the sorption capacity determined by means of the Langmuir isotherm may be characterised by significant uncertainty of measurements, which is very frequently not stated by the authors [12]. Due to different testing and interpretation methods, it is often difficult to compare the test results.

The objective of the tests was to assess the sorption properties of algae Spirogyra sp., to determine sorption preferences in relation to selected heavy metal cations $\left(\mathrm{Cu}^{2+}, \mathrm{Zn}^{2+}\right.$ and $\mathrm{Cd}^{2+}$ ) and to define the impact of $\mathrm{H}^{+}, \mathrm{Na}^{+}$and $\mathrm{Ca}^{2+}$ cations naturally present in the alga environment on manganese accumulation in thalli of these algae. The tests involved a dynamic flow of the solution through the alga sample in order to maintain constant concentrations of analytes in the solution during the sorption process. These conditions of the experiment were to simulate natural conditions. The results were compared to the results obtained for sea algae Palmaria palmata with the same parameters of sample preparation and analyses. The presented data may be used in the planning of processes of water phytoremediation using algae and may improve the reliability of active water biomonitoring.

\section{Materials and methods}

Algae Spirogyra sp., collected from a slightly polluted body of water formed after gravel extraction and located in Opole (PL), were used in tests. Having removed the plants and aquatic organisms, alga samples were rinsed with demineralised water. The cleaned 
samples were dehydrated by freeze-drying at $223^{\circ} \mathrm{K}$ for $20 \mathrm{~h}$. The prepared algae were kept in tightly sealed polyethylene containers.

Sea algae Palmaria palmata were also used in tests on the impact of cations naturally present in the aquatic environment.

Before each experiment, the dried algae were immersed in demineralised water for 30 minutes (conductivity $\kappa=0.5 \mu \mathrm{S} / \mathrm{cm}$ ) [13].

Metals were determined by atomic absorption spectrometry, with the use of iCE 3000 unit manufactured by Thermo Electron Corporation, USA.

\section{Determination of heavy metal sorption preferences in relation to thalli of algae Spirogyra sp.}

The sorption preferences were determined based on the affinity of selected heavy metal cations ( $\mathrm{Mn}, \mathrm{Cu}, \mathrm{Zn}, \mathrm{Cd}$ and $\mathrm{Pb}$ ) to active centres of algae. For this purpose, $0.500 \pm 0.001 \mathrm{~g}$ d.m. (dry mass) alga samples were placed in a perforated container of approximately $15 \mathrm{~cm}^{3}$ and immersed for 30 minutes in a $400 \mathrm{~cm}^{3}$ solution of cations of one of the metals. The same sample, having been rinsed with demineralised water, was placed for another 30 minutes in a $400 \mathrm{~cm}^{3}$ solution of another metal. This experiment was carried out for each pair of the tested metals, also by changing their sequence. The concentrations of the subsequent pairs of metals were determined in the final solution. The solutions had the initial concentration of $0.041 \mathrm{mmol} / \mathrm{dm}^{3}$.

\section{Analysis of the impact of $\mathrm{H}^{+}, \mathrm{Na}^{+}$and $\mathrm{Ca}^{2+}$ on the sorption of manganese in algae in dynamic conditions}

$0.500 \pm 0.001 \mathrm{~g}$ d.m. alga samples were placed in a perforated container of approximately $15 \mathrm{~cm}^{3}$ and inserted into a sorption column through which a $\mathrm{MnCl}_{2}$ solution was flown for 30 minutes. The sorption process was carried out with a dynamic flow of the solution having the constant concentration of analytes through the alga sample.

The concentration of manganese cations was constant during the tests and only $\mathrm{pH}$ of the solutions and their conductivity (by adding $\mathrm{Na}$ or $\mathrm{Ca}$ salts) was being changed. The $\mathrm{pH}$ of the solutions was changed by adding $0.1 \mathrm{M} \mathrm{HCl}$ or $0.1 \mathrm{M} \mathrm{NaOH}$ and their conductivity was changed by adding sodium or calcium chlorides. $\mathrm{Na}^{+}$and $\mathrm{Ca}^{2+}$ salts were added at different concentrations in order to maintain the conductivity of the solutions within the range between 60 and $1.400 \mu \mathrm{S} / \mathrm{cm}$.

The conductivity of the solutions was measured by a conductometer CC551 manufactured by Elmetron Sp.j. from Zabrze (PL), whose absolute error of readings was $\Delta \kappa=0.1 \mu \mathrm{S} / \mathrm{cm}$. The $\mathrm{pH}$ of solutions in which alga samples were immersed was measured with a CP551 pH-meter manufactured by Elmetron Sp.j. from Zabrze (PL). The absolute error of readings was $\Delta \mathrm{pH}=0.02$.

The algae samples (dry mass each of them was $0.500 \pm 0.001 \mathrm{~g}$ ) were mineralised in the mixture of nitric(V) acid and hydrochloric acid $\left(\mathrm{HNO}_{3} 65 \%: \mathrm{HCl} 37 \%=1: 3\right)$ using a Speedwave Four microwave oven manufactured by Berghof (DE). The mineralisation process temperature was $180^{\circ} \mathrm{C}$. MERCK reagents were used to prepare the solutions.

The concentration of manganese naturally accumulated in algae Spirogyra sp. was $c_{M n(a, 0)}=0.0550 \pm 0.0008 \mathrm{mg} / \mathrm{g} \mathrm{d} . \mathrm{m}$. 


\section{Quality control}

Calibration of spectrometer was performed with a standard solution from ANALYTIKA Ltd. (Czech Republic). The values of the highest concentrations of the models used for calibration $\left(2 \mathrm{mg} / \mathrm{dm}^{3}\right.$ for $\mathrm{Cd}, 5 \mathrm{mg} / \mathrm{dm}^{3}$ for $\mathrm{Cu}, \mathrm{Zn}$ and $7.5 \mathrm{mg} / \mathrm{dm}^{3}$ for $\mathrm{Mn})$ were approved as linear limits of the signal dependence on the concentration.

Table 1 shows the concentrations of metal element determined in the reference material BCR 414 (plankton) and BCR 482 (lichen), using the AAS spectrometer.

Table 1

Comparison of the measured and certified data in BCR 414 (plankton) and BCR 482 (lichen); $\pm S D$ - Standard deviation, $\mathrm{Cv}$ - Certified value, $\pm U$ - Uncertainty, Dev - Deviation: the relative difference between concentrations measured by AAS and certified concentrations in [\%]

\begin{tabular}{|c|c|c|c|c|c|c|c|c|c|c|}
\hline \multirow{3}{*}{ Element } & \multicolumn{2}{|c|}{ AAS } & \multicolumn{2}{|c|}{ BCR 414 plankton } & \multirow[t]{2}{*}{ Dev. } & \multicolumn{2}{|c|}{ AAS } & \multicolumn{2}{|c|}{ BCR 482 lichen } & \multirow[t]{2}{*}{ Dev. } \\
\hline & Mean & $\pm S D$ & $\mathrm{Cv}$ & $\pm U$ & & Mean & $\pm S D$ & $\mathrm{Cv}$ & $\pm U$ & \\
\hline & \multicolumn{4}{|c|}{ [ $\mu \mathrm{g} / \mathrm{g}$ d.m.] } & {$[\%]$} & \multicolumn{4}{|c|}{ [ $\mu \mathrm{g} / \mathrm{g}$ d.m.] } & {$[\%]$} \\
\hline $\mathrm{Mn}$ & 284 & 13 & 299 & 12 & -5.0 & 31.7 & 0.6 & 33.0 & 0.5 & -3.9 \\
\hline $\mathrm{Cu}$ & 28.4 & 1.6 & 29.5 & 1.3 & -3.7 & 6.63 & 0.17 & 7.03 & 0.19 & -5.7 \\
\hline $\mathrm{Zn}$ & 107 & 3 & 112 & 3 & -4.5 & 95.1 & 2.3 & 100.6 & 2.2 & -5.5 \\
\hline $\mathrm{Cd}$ & - & - & 0.383 & 0.014 & - & 0.53 & 0.03 & 0.56 & 0.02 & -5.3 \\
\hline
\end{tabular}

\section{Results and discussion}

The assessment of the sorption preferences of manganese in algae Spirogyra sp. with reference to selected heavy metals and the impact of cations naturally present in the environment on sorption efficiency is presented below. The results were compared to the results of tests on sea algae Palmaria palmata.

\section{Determination of heavy metal sorption preferences in algae Spirogyra sp.}

The sorption preferences of algae Spirogyra sp. were determined using the procedure described in section Materials and methods. The sorption preferences are the most frequently determined on the basis of the Langmuir isotherm parameters. However, research shows that these measurements may be subject to a significant error [12]. Table 2 shows the possibility of mutual desorption of heavy metal cations previously absorbed as a result of ion exchange in algae Spirogyra sp. The $c_{(s, 1)}$ values in the Table show the concentration of desorbed metals in the solution at equilibrium.

Table 2

The possibility of mutual desorption of heavy metal cations from thalli of algae Spirogyra sp.;

$C V$ - Coefficient of variation

\begin{tabular}{|c|c|c|c|c|}
\hline \multirow{2}{*}{$\begin{array}{c}\text { Adsorbing } \\
\text { metal }\end{array}$} & \multicolumn{3}{|c|}{$\boldsymbol{c}_{(\mathrm{s}, \mathbf{l})}$ of adsorbed metal $\left[\mathbf{m m o l} / \mathbf{d m}^{\mathbf{3}}\right] \pm \boldsymbol{C V}^{*}[\boldsymbol{\%}]$} \\
\cline { 2 - 5 } & $\mathbf{M n}$ & $\mathbf{C u}$ & $\mathbf{Z n}$ & $\mathbf{C d}$ \\
\hline $\mathrm{Mn}$ & - & $0.000082 \pm 11$ & $0.0024 \pm 6.5$ & $0.0027 \pm 12$ \\
\hline $\mathrm{Cu}$ & $0.0017 \pm 11$ & - & $0.0017 \pm 8.6$ & $0.0037 \pm 11$ \\
\hline $\mathrm{Zn}$ & $0.0015 \pm 6.2$ & $0.0006 \pm 8.4$ & - & $0.0024 \pm 9.7$ \\
\hline $\mathrm{Cd}$ & $0.0021 \pm 12$ & $0.0000047 \pm 10$ & $0.0031 \pm 9.9$ & - \\
\hline
\end{tabular}

Based on the carried out tests, it was found that copper cations desorbed from algae approximately 800 times more cadmium cations $\left(0.0037 \mathrm{mmol} / \mathrm{dm}^{3}\right)$ as compared to the 
reverse process when $\mathrm{Cd}^{2+}$ cations desorbed $\mathrm{Cu}^{2+}$ cations $\left(0.0000047 \mathrm{mmol} / \mathrm{dm}^{3}\right)$. Other statistically significant correlations suggest the position of manganese in a sequence of the affinity of metals to thalli of Spirogyra sp. as follows: $\mathrm{Zn}^{2+}<\mathrm{Cd}^{2+} \approx \mathrm{Mn}^{2+}<\mathrm{Cu}^{2+}$. For comparison, the affinity of heavy metals to thalli of sea algae Palmaria palmata changes as follows: $\mathrm{Mn}^{2+}<\mathrm{Zn}^{2+} \approx \mathrm{Cd}^{2+}<\mathrm{Cu}^{2+}$. In the case of sea algae, the number of $\mathrm{Cd}^{2+}$ cations desorbed by $\mathrm{Cu}^{2+}$ ions from their thalli was only 9 times greater $\left(0.009 \mathrm{mmol} / \mathrm{dm}^{3}\right)$ than the number of $\mathrm{Cu}^{2+}$ cations desorbed by $\mathrm{Cd}^{2+}\left(0.001 \mathrm{mmol} / \mathrm{dm}^{3}\right)$ [14]. The shown correlations occur regardless of the scale of the experiment, probably also in the case of wastewater treatment using biosorbents.

\section{Analysis of the impact of $\mathrm{H}^{+}, \mathrm{Na}^{+}$and $\mathrm{Ca}^{2+}$ on the sorption of manganese in algae Spirogyra sp. and Palmaria palmata}

First, the solutions of $\mathrm{Mn}^{2+}$ salts at the concentration of $0.52 \mathrm{mg} / \mathrm{dm}^{3}\left(0.01 \mathrm{mmol} / \mathrm{dm}^{3}\right)$, enriched with protons $(\mathrm{pH}=3.0), \mathrm{Na}^{+}$cations $(\kappa=112 \mu \mathrm{S} / \mathrm{cm})$ and $\mathrm{Ca}^{2+}$ cations $(\kappa=112 \mu \mathrm{S} / \mathrm{cm})$, were flown through alga samples. These solutions had comparable concentrations of $\mathrm{H}^{+}, \mathrm{Na}^{+}$and $\mathrm{Ca}^{2+}$ as per unit ion charge: $c^{*}=z \cdot c=1.0 \mathrm{~mol} / \mathrm{dm}^{3}$ ( $z$ - cation valence, dimensionless value). The concentrations of manganese accumulated in algae after the process of sorption from solutions enriched with $\mathrm{H}^{+}, \mathrm{Na}^{+}$and $\mathrm{Ca}^{2+}$ cations as compared to the concentration of manganese from the solution with no other cations added is shown on the diagram in Figure 1.

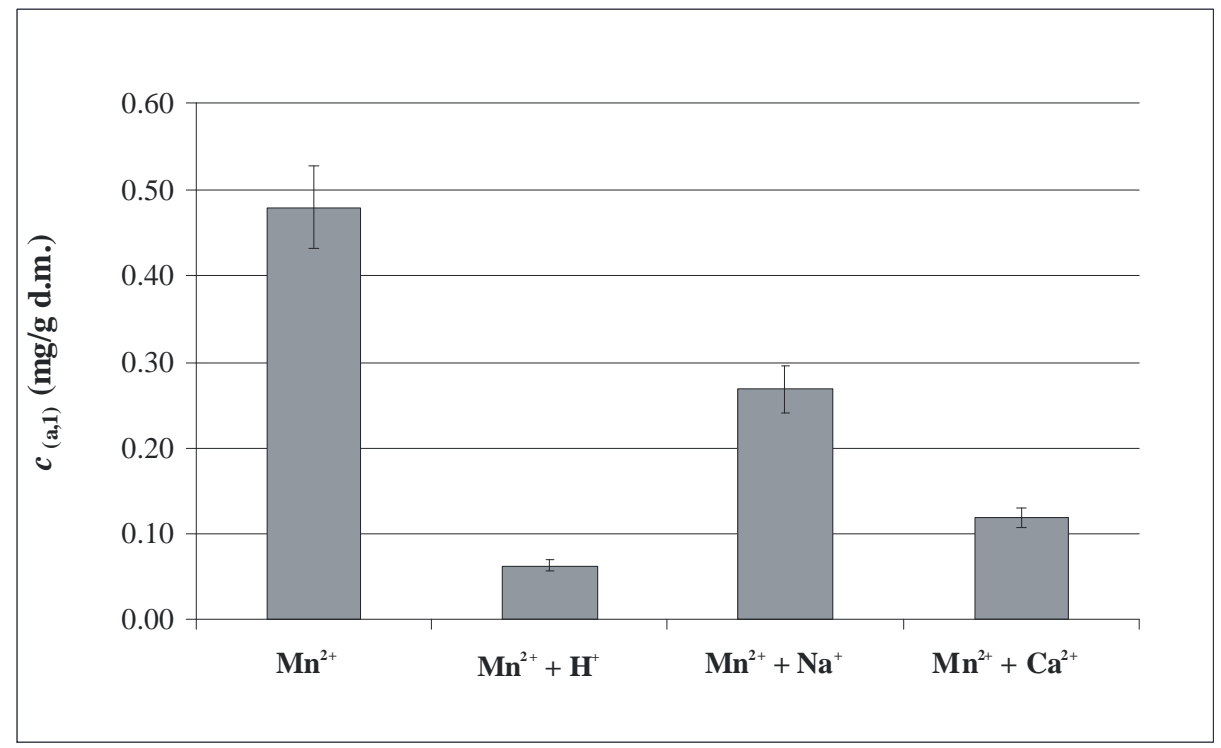

Fig. 1. The impact of $\mathrm{H}^{+}, \mathrm{Na}^{+}$and $\mathrm{Ca}^{2+}$ cations on the sorption of manganese in algae Spirogyra sp.

The diagram shows that the competitiveness of the sorption of cations naturally present in the alga environment versus $\mathrm{Mn}^{2+}$ cations changes in the following sequence: $\mathrm{Na}^{+}<\mathrm{Ca}^{2+}<\mathrm{H}^{+}$as per unit ion charge. Similar results were obtained for sea algae Palmaria palmata [7]. 

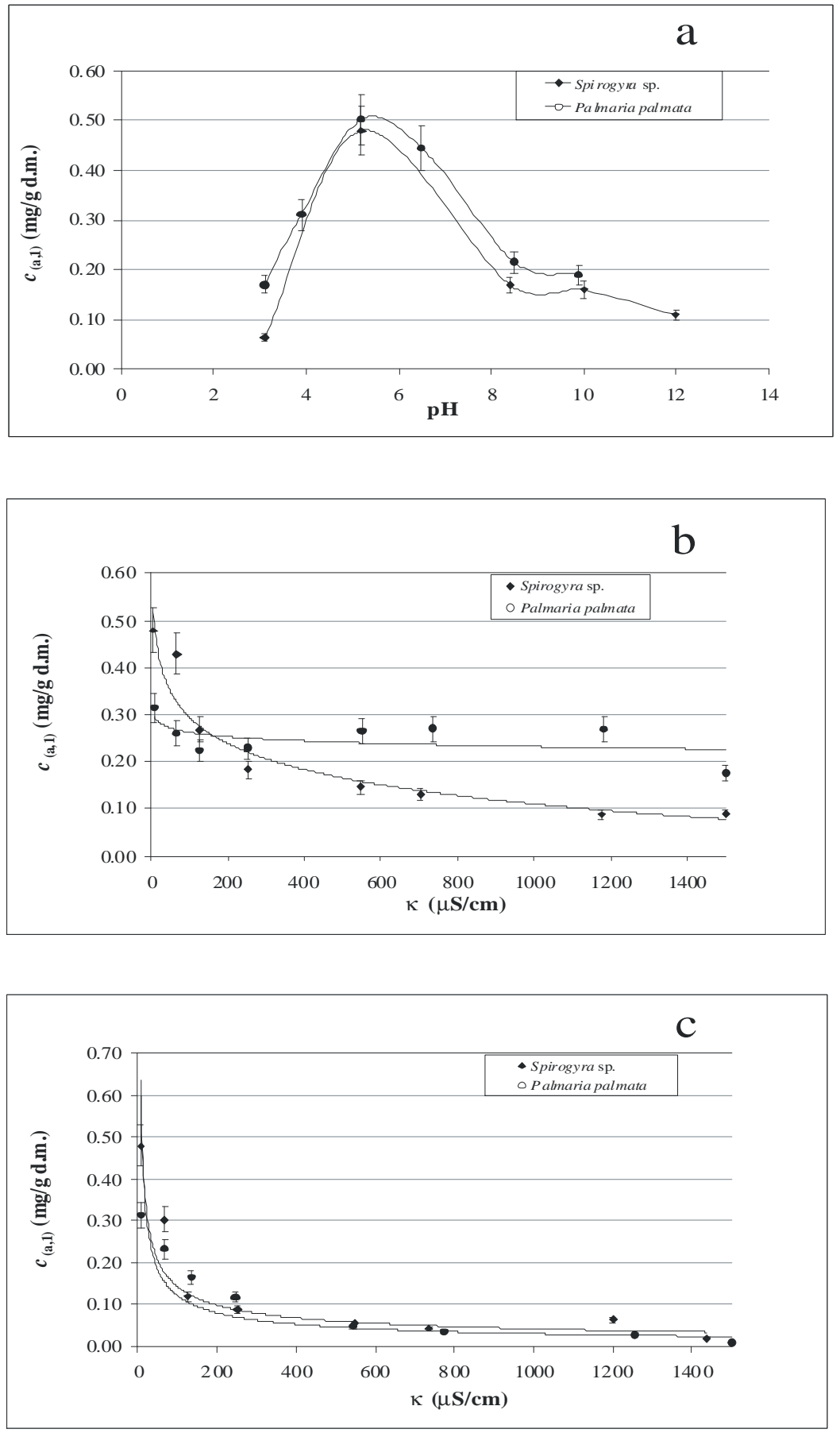

Fig. 2. The impact of the concentration of $\mathrm{H}^{+}(\mathrm{a}), \mathrm{Na}^{+}$(b) and $\mathrm{Ca}^{2+}$ (c) on the sorption of manganese in algae Spirogyra sp. and Palmaria palmata 
The impact of the concentration of these cations on the efficiency of the sorption of manganese cations in algae Spirogyra sp. and Palmaria palmata is shown on the diagrams in Figure 2. Changes in the concentration of hydrogen cations are expressed on a logarithmic scale $(\mathrm{pH})$ and changes in the concentration of $\mathrm{Na}^{+}$and $\mathrm{Ca}^{2+}$ cations are expressed through changes in conductivity of the solutions. This is of practical relevance for the in situ assessment of water salinity by a simple measurement of conductivity. The empirically determined linear correlation $\kappa=113 \cdot c^{*}+0.05$ makes it possible to determine the concentration of the sum of cations (as mentioned above, $c^{*}=z \cdot c$ ) as far as low concentrations of electrolytes are concerned [15].

Figure 2a shows that the maximum sorption occurs in the stock solution with manganese salts and a few ions contained in demineralised water used to prepare the solutions ( $\mathrm{pH}=5.2$ ). With acidification of the solution, the number of absorbed manganese ions decreases in consequence of the competitive sorption of hydrogen cations, whereas during alkalisation the $\mathrm{Mn}^{2+}$ ion forms change and form $\mathrm{Mn}(\mathrm{OH})_{2}$, reducing the concentration of bioavailable $\mathrm{Mn}^{2+}$ forms in the solution. The presence of $\mathrm{Na}^{+}$cations, introduced with $\mathrm{OH}^{-}$groups, is also important as they also reduce $\mathrm{Mn}^{2+}$ sorption as shown in Figures 1 and $2 \mathrm{~b}$. The similar impact of $\mathrm{pH}$ on the sorption of heavy metals in biosorbents is also confirmed by other authors. For example, tests on algae Ceramium virgatum showed that the maximum sorption of cadmium cations $(96 \%$ of biosorption efficiency) in this alga species may be achieved at $\mathrm{pH}=5.0$. It was found that $90 \%$ of $\mathrm{Cd}^{2+}$ cations were absorbed at $\mathrm{pH}=4.5$ as a result of the competitive sorption of hydrogen cations from the solution, while the increase in $\mathrm{pH}$ reduced the process efficiency, which according to the authors was related to the formation of complexes with hydroxyl groups [16]. In others tests it was shown that changes in $\mathrm{pH}$ of $\mathrm{Cu}^{2+}$ and $\mathrm{Pb}^{2+}$ salt solutions (concentration of analyte in the solution: $100 \mathrm{mg} / \mathrm{dm}^{3}$ ) within the range $5.8<\mathrm{pH}<8.5 \mathrm{had}$ no impact on the concentration of these metals accumulated in algae Ecklonia maxima. It is possible that while interpreting the results the authors failed to take into account the fact that the lack of the increase in the concentration of copper and lead in algae could be due to precipitation of insoluble hydroxides in the solution and thereby the reduction in their sorption by alga thalli [17]. The impact of the increase in $\mathrm{pH}$ on the formation of insoluble metal hydroxides in the solution was also reported by other authors [18].

The results on Figures $2 \mathrm{~b}$ and $2 \mathrm{c}$ show that $\mathrm{Na}^{+}$and $\mathrm{Ca}^{2+}$ cations also reduce the sorption of manganese in freshwater algae Spirogyra sp. and sea algae Palmaria palmata. The impact of cations naturally present in the alga environment on the sorption of heavy metals was also reported by other authors [19]. The presence of $\mathrm{K}^{+}, \mathrm{Mg}^{2+}$ and $\mathrm{Ca}^{2+}$ cations in the $\mathrm{Cu}^{2+}$ salt solution decreased the concentrations of metal cations absorbed in algae Padina sp. by $4 \%, 11 \%$ and $13 \%$ respectively [20]. $\mathrm{Na}^{+}$and $\mathrm{K}^{+}$ions (at concentrations of 0-10 mM) had no impact on the sorption of $\mathrm{Pb}^{2+}$ and $\mathrm{Cu}^{2+}$ cations in algae Ecklonia radiata, whereas $\mathrm{Ca}^{2+}$ and $\mathrm{Mg}^{2+}$ ions reduce the concentration of metal cations absorbed in alga thalli by $10-18 \%$ and 5-10\% respectively, depending on the concentration of $\mathrm{Ca}^{2+}$ and $\mathrm{Mg}^{2+}$ $(0-10 \mathrm{mM})$ [21]. The test results also indicate that different species of algae have different sorption properties. In the case of algae Spirogyra sp. and Palmaria palmata, the correlations in relation to chemical affinity of cations are the same, as shown in Figure 1. However, the diagrams in Figure 2 indicate different competitiveness of cations naturally present in the aquatic environment in relation to cations of manganese absorbed in algae Spirogyra sp. and Palmaria palmata. As far as $\mathrm{H}^{+}$and $\mathrm{Ca}^{2+}$ are concerned, these differences 
are statistically insignificant, but significantly reduced impact of sodium cations on the sorption of manganese in algae Palmaria palmata was observed. Looking for this type of correlations may facilitate the proper choice of biosorbent to be used in order to remove heavy metals from water and wastewater.

Furthermore, as far as the possibility of using Palmaria palmata to assess the pollution of surface water is concerned, it is interesting that there are no statistically significant changes in the quantity of absorbed $\mathrm{Mn}^{2+}$ within the range of conductivity changes between 200 and $1000 \mu \mathrm{S} / \mathrm{cm}$ due to the presence of calcium cations and also, in contrast to algae Spirogyra sp., of sodium cations.

It is to be expected that in natural freshwater bodies, in which the water conductivity is usually between 200 and $800 \mu \mathrm{S} / \mathrm{cm}$, the presence of sodium and calcium will not affect the manganese partition coefficients in the algae/water system, which may be useful in the assessment of water pollution by measuring analytes in the exposed algae Palmaria palmata.

\section{Conclusions}

Algae, regardless of the ecosystem they live in, accumulate heavy metals from the solutions with which they come into contact. The affinity of heavy metals to thalli of algae Spirogyra sp., determined in the course of the carried out tests, increases as follows: $\mathrm{Zn}^{2+}<\mathrm{Cd}^{2+} \approx \mathrm{Mn}^{2+}<\mathrm{Cu}^{2+}$, and the affinity to thalli of algae Palmaria palmata changes as follows: $\mathrm{Mn}^{2+}<\mathrm{Zn}^{2+} \approx \mathrm{Cd}^{2+}<\mathrm{Cu}^{2+}$. Cations naturally present in water, including $\mathrm{H}^{+}, \mathrm{Na}^{+}$ and $\mathrm{Ca}^{2+}$, affect the sorption of heavy metals in thalli of freshwater and sea algae. As the affinity and competitive sorption of cations differ in the case of various algae, looking for correlations between these factors may be of relevance when choosing a biosorbent to be used in order to remove heavy metals from water and wastewater and in biomonitoring research.

\section{Acknowledgements}

"The Project received financial assistance from the funds of the National Science Centre granted by force of the decision No. DEC-2011/03/D/NZ9/00051."

\section{References}

[1] Yalçın S, Sezer S, Apak R. Characterization and lead(II), cadmium(II), nickel(II) biosorption of dried marine brown macro algae Cystoseira barbata. Environ Sci Pollut Res. 2012;19:3118-3125. DOI: 10.1007/s11356-012-0807-2.

[2] Kang KH, Sui Z. Removal of eutrophication factors and heavy metal from a closed cultivation system using the macroalgae, Gracilaria sp. (Rhodophyta). Chinese J Oceanol Limnol. 2010;28:1127-1130.

[3] Monteiro CM, Castro PML, Malcata FX. Use of the microalga Scenedesmus obliquus to remove cadmium cations from aqueous solutions. World J Microbiol Biotechnol. 2009;25:1573-1578.

[4] Pawlik-Skowrońska B. Tajemnice odporności glonów i sinic na toksyczne metale ciężkie [Secrets of algae and cyanobacteria resistance to toxic heavy metals]. Kosmos. 2002;51:175-184.

[5] Davis TA, Volesky B, Mucci A. A review of the biotechnology of heavy metal biosorption by brown algae. Water Res. 2003;37:4311-4330. DOI:10.1016/S0043-1354(03)00293-8.

[6] Praveen KM, Suparna M. Biosorption of diesel and lubricating oil on algal biomass. Biotechnology. 2012;2:301-310. DOI: 10.1007/s13205-012-0056-6.

[7] Rajfur M, Kłos A. Sorption of heavy metals in the biomass of algae Palmaria palmata. Water Sci Technol. 2013;68(7):1543-1549. DOI: 10.2166/wst.2013.400. 
[8] Bulgariu D, Bulgariu L. Equilibrium and kinetics studies of heavy metal ions biosorption on green algae waste biomass. Bioresour Technol. 2012;103:489-493. DOI: 10.1016/j.biortech.2011.10.016.

[9] Çelekli A, Bozkurt H. Bio-sorption of cadmium and nickel ions using Spirulina platensis: Kinetic and equilibrium studies. Desalination. 2011;275:141-147. DOI: 10.1016/j.desal.2011.02.013.

[10] Arecoa MM, Hanelab S, Duranb J, dos Santos Afonsoa M. Biosorption of Cu(II), Zn(II), Cd(II) and Pb(II) by dead biomasses of green alga Ulva lactuca and the development of a sustainable matrix for adsorption implementation. J Hazard Mater. 2012;213-214:123- 132. DOI: 10.1016/j.jhazmat.2012.01.073.

[11] Zakhama S, Dhaouadi H, M'Henni F. Nonlinear modelisation of heavy metal removal from aqueous solution using Ulva lactuca algae. Bioresour Technol. 2011;102:786-796.

[12] Rajfur M, Kłos A, Wacławek M. Sorption properties of algae Spirogyra sp. and their use for determination of heavy metal ions concentrations in surface water. Bioelectrochemistry. 2010;80:81-86. DOI: 10.1016/j.bioelechem.2010.03.005.

[13] Rajfur M, Kłos A, Wacławek M. Sorption of copper(II) ions in the biomass of alga Spirogyra sp. Bioelectrochemistry. 2012;87:65-70. DOI: 10.1016/j.bioelechem.2011.12.007.

[14] Rajfur M, Kłos A, Wacławek M. Biosorption of heavy metals from aqueous solutions by red algae Palmaria palmata: Study of the kinetics and the equilibrium of sorption. In: Environ Eng. Pawłowski L, Dudzińska MR, Pawłowski A, editors. London: Taylor \& Francis Group; 2013:533-540.

[15] Kłos A. Porosty w biomonitoringu środowiska [Lichens in environmental biomonitoring]. Opole: Wydaw Uniw Opolskiego; 2009.

[16] Sari A, Tuzen M. Biosorption of cadmium(II) from aqueous solution by red algae (Ceramium virgatum): Equilibrium, kinetic and thermodynamic studies. J Hazard Mater. 2008;157:448-454. DOI: 10.1016/j.jhazmat.2008.01.008.

[17] Feng D, Aldrich C. Adsorption of heavy metals by biomaterials derived from the marine alga Ecklonia maxima. Hydrometallurgy. 2004;73:1-10. DOI: 10.1016/S0304-386X(03)00138-5.

[18] Perelygin YP, Rashevskaya IV. On the Term "pH of the precipitation onset of heavy metal hydroxides". Russian J Appl Chem. 2006;79:492-493.

[19] Herrero R, Lodeiro P, Rey-Castro C, Vilarino T, Sastre de Vicente ME. Removal of inorganic mercury from aqueous solutions by biomass of the marine macroalga Cystoseira baccata. Water Res. 2005;39:3199-3210. DOI: 10.1016/j.watres.2005.05.041.

[20] Kaewsarn P. Biosorption of copper(II) from aqueous solutions by pre-treated biomass of marine algae Padina sp. Chemosphere. 2002;47:1081-1085. PII: S0045-6535(01)00324-1.

[21] Matheickal JT, Yu Q. Biosorption of lead from aqueous solutions by marine algae Ecklonia radiate. Water Sci Technol. 1996;34:1-7. DOI: pjbs.2002.332.334.

\title{
WPLYW RÓŻNYCH KATIONÓW NA SORPCJĘ MANGANU W PLESZE SŁODKOWODNYCH GLONÓW Spirogyra sp. ORAZ W GLONACH MORSKICH Palmaria palmata
}

\author{
${ }^{1}$ Samodzielna Katedra Biotechnologii i Biologii Molekularnej, Uniwersytet Opolski \\ ${ }^{2}$ Samodzielny Zakład Ochrony i Kształtowania Środowiska \\ Uniwersytet Humanistyczno-Przyrodniczy Jana Kochanowskiego w Kielcach
}

\begin{abstract}
Abstrakt: Glony ze względu na występowanie w bardzo zróżnicowanych warunkach i dużą odporność na czynniki fizykochemiczne należą do pionierów zasiedlających nowe środowiska, a ich właściwości sorpcyjne są wykorzystywane w biomonitoringu i remediacji wód. Wydajność procesu sorpcji metali ciężkich na glonach wykorzystywanych do badań in situ uzależniona jest od czynników abiotycznych, m.in. od składu chemicznego wody. Do badań wykorzystano słodkowodne glony Spirogyra sp., które w warunkach laboratoryjnych eksponowano w roztworach chlorku manganu o różnym udziale innych kationów, m.in. metali ciężkich i makroelementów. Wykazano, że niektóre metale ciężkie mogą desorbować mangan związany powierzchniowo na glonach wskutek wymiany jonowej, w szeregu $\mathrm{Cd}^{2+}<\mathrm{Mn}^{2+} \approx \mathrm{Zn}^{2+}<\mathrm{Cu}^{2+}$. Stwierdzono również, że konkurencyjność sorpcji kationów naturalnie występujących w środowisku bytowania glonów w stosunku do kationów $\mathrm{Mn}^{2+}$ zmienia się zgodnie $\mathrm{z}$ szeregiem: $\mathrm{Na}^{+}<\mathrm{Ca}^{2+}<\mathrm{H}^{+}$, wyznaczonym dla stężeń molowych odniesionych do jednostkowego ładunku kationu. Wyniki badań porównano z wynikami analiz przeprowadzonych na suszonych glonach morskich Palmaria palmata.
\end{abstract}

Słowa kluczowe: Spirogyra sp., Palmaria palmata, wymiana jonowa, metale ciężkie, konkurencyjność sorpcji 